\title{
PENGARUH LITERASI KEUANGAN, SELF CONTROL DAN RISK TOLERANCE TERHADAP KEPUTUSAN INVESTASI MELALUI PERILAKU KEUANGAN (Studi Kasus Karyawan Bank BUMN di Kota Depok)
}

\author{
${ }^{1 *}$ Jeria Tati Darwati, ${ }^{2}$ Zulkifli, ${ }^{3}$ Widarto Rachbini \\ Universitas Pancasila, Jakarta Selatan, DKI Jakarta, Indonesia \\ *jeriatd@gmail.com
}

\begin{abstract}
Abstrak
Penelitian ini bertujuan untuk mengetahui pengaruh literasi keuangan terhadap perilaku keuangan, pengaruh self control terhadap perilaku keuangan, risk tolerance terhadap perilaku keuangan, literasi keuangan terhadap keputusan investasi, self control terhadap keputusan investasi, risk tolerance terhadap keputusan investasi, dan perilaku keuangan terhadap keputusan investasi. Penelitian ini menggunakan pendekatan kuantitatif dan bersifat ekspositori. Penelitian dilakukan pada karyawan perbankan BUMN di Kota Depok dan dilaksanakan selama 6 bulan dimulai dari bulan Maret 2021 sampai dengan bulan Juli 2021. Variabel penelitian ini terdiri dari X1 literasi keuangan, X2 self control, $\mathrm{X} 3$ risk tolerance, $\mathrm{Y}$ keputusan investasi, dan Z perilaku keuangan. Populasi adalah seluruh karyawan perbankan BUMN di Kota Depok, sehingga didapatkan sampel menggunakan rumus slovin sebanyak 203 responden yang nantinya akan disebarkan kuesioner. Teknik analisis data menggunakan Structural Equation Modeling (SEM) dengan menggunakan software SmartPLS. Hasil penelitian menunjukkan bahwa literasi keuangan dan self control berpengaruh signifikan terhadap perilaku keuangan, kecuali risk tolerance tidak berpengaruh pada perilaku keuangan. Selain itu, literasi keuangan, self control, risk tolerance dan perilaku keuangan berpengaruh signifikan terhadap keputusan investasi.
\end{abstract}

Kata Kunci: Literasi Keuangan, Self Control, Risk Tolerance, Keputusan Investasi, Perilaku Keuangan

\section{Abstract}

This study aims to determine the effect of financial literacy on financial behavior, the effect of self control on financial behavior, risk tolerance on financial behavior, financial literacy on investment decisions, self control on investment decisions, risk tolerance on investment decisions, and financial behavior on investment decisions. This research uses a quantitative and expository approach. The study was conducted on BUMN banking employees in Depok City and was carried out for 6 months starting from March 2021 to July 2021. The variables of this study consisted of X1 financial literacy, X2 self control, X3 risk tolerance, Y investment decisions, and Z financial behavior. . The population is all BUMN banking employees in Depok City, so that a sample using the Slovin formula is obtained as many as 203 respondents which will later be distributed questionnaires. The data analysis technique used Structural Equation Modeling (SEM) using SmartPLS software. The results showed that financial literacy and self-control had a significant effect on financial behavior, except that risk tolerance had no effect on financial behavior. In addition, financial literacy, self control, risk tolerance and financial behavior have a significant effect on investment decisions.

Keywords: Financial Literacy, Self Control, Risk Tolerance, Investment Decisions, Financial Behavior

\section{PENDAHULUAN}

Dalam merencanakan keuangan, khususnya dengan keputusan investasi perlu pengetahuan dan riset yang mendalam. Hal ini dilakukan untuk melakukan proteksi atas risiko-risiko yang tidak terduga. Setiap investor memiliki kemampuan untuk menanggung risiko dan keuntungan dengan tingkat yang berbedabeda, maka nantinya dapat merencanakan tujuan investasi dengan jelas, sehingga tidak sekedar ikut-ikutan demi mendapatkan keuntungan instan di pasar modal (Amri, 2021).

Meningkatnya minat masyarakat saat ini dalam berinvestasi saham mulai 
mengkhawatirkan, karena hal ini tidak dibarengi dengan pengetahuan dan risiko investasi investor di bursa saham. Ajakan untuk memilih saham tertentu pun makin marak terjadi oleh kalangan tertentu yang tidak hanya di Indonesia, tetapi juga pasar bursa di dunia. Jika ini terus terjadi, maka akan terjadi penggiringan pembelian yang akan merusak stabilitas harga saham (www.idxchannel.com, 2021). Hal ini dapat merugikan para investor tersebut dalam berinvestasi. Tingginya antusias masyarakat untuk investasi dan minimnya ilmu pengetahuan membuat mereka mudah mempercayai promosi dari kalangan orangorang yang berpengaruh di media sosial atas sebuah saham, sehingga memunculkan masalah tersendiri bagi investor dan pasar modal (Amri \& Ramdani, 2020).

$$
\text { Menurut Halim (2005) dalam }
$$
investasi di pasar modal diperlukan pengetahuan yang memadai, pengalaman serta naluri bisnis untuk menganalisis saham-saham mana yang akan dibeli. Pengetahuan yang cukup sangat diperlukan untuk menghindari terjadinya kerugian saat melakukan investasi di pasar modal. Investor juga harus memahami bahwa saham bersifat fluktuatif, bisa naik atau turun seperti halnya dengan harga barang atau komoditi di pasar (www.money.Kompas.com, 2021).

Investasi di pasar modal menjanjikan pengembalian yang besar. Pasar modal memberikan kesempatan kepada investor untuk memilih produk pasar modal yang diperdagangkan. Sehingga dapat menganalisa suatu perusahaan sebelum dibeli sahamnya. Investor diharapkan memiliki ilmu keuangan yang memadai (Ramdani et al., 2021). Tingkat literasi keuangan investor dalam mengambil keputusan investasi sangat penting, sehingga investor dapat mengelola dananya secara bijak dan tepat. Tanpa pengelolaan dana yang baik sebanyak apapun profit yang didapat tidak akan berkembang dan akan menjadi sia-sia.

Penambahan investor ritel baru atau lokal merupakan kabar baik untuk pasar modal, namun ternyata ada efek samping yang membuat geleng-geleng kepala. Minat masyarakat Indonesia terhadap investasi di pasar modal semakin tinggi. Terbukti dari jumlah investor pasar modal yang meningkat $56 \%$ di sepanjang 2020 menjadi 3,87 juta. Menariknya lagi penambahan jumlah investor ritel di pasar modal Indonesia itu didominasi oleh kalangan milenial. Namun sayangnya penambahan jumlah investor itu sepertinya tidak dibarengi dengan edukasi yang mumpuni. Terbukti dari fenomena-fenomena yang muncul belakangan ini. Seperti para influencer yang justru dipercaya menjadi rujukan dalam memilih saham. Tak hanya itu, muncul juga fenomena investor yang membeli saham menggunakan uang panas. Mulai dari utang pinjaman online, menggunakan uang titipan arisan ibu-ibu PKK hingga nekat menggadaikan surat tanah dan BPKB (www.finance.detik.com, 2021).

Dalam proses investasi diperlukan waktu dan proses panjang, sehingga tidak bisa mendapat hasil secara instan. Disarankan investor tidak menggunakan uang panas yang artinya uang untuk kebutuhan sehari-hari. Investasi harus disesuaikan dengan pengelolaan keuangan masing-masing. Tidak mudah ikut-ikutan dan percaya ajakan dari orang lain. Maka investor harus memiliki pengetahuan lebih lanjut karena setiap produk investasi di pasar modal memiliki potensi keuntungan dan resikonya masing-masing yang berbeda (Amri, Widyastuti, et al., 2021).

Terdapat beberapa hal yang mendasari investor dalam mengambil keputusan investasi, yaitu return (keuntungan) dan risk (risiko). Keuntungan memiliki korelasi yang positif dengan risiko karena investasi itu mengandung'high risk high return'. Di saat seorang investor menginginkan return yang tinggi, maka investor akan menghadapi risk yang tinggi juga. Begitu pula sebaliknya. Dalam keputusan investasi, investor akan melihat faktor risk dan return (Ramadhi et al., 2021). Dalam memutuskan suatu investasi, investor akan dihadapkan dengan banyak pilihan jenis investasi, hal ini merupakan 
masalah bagi investor untuk menentukan pada investasi mana dananya akan ditanamkan. Sehingga akan menghasilkan banyak keuntungan di masa yang akan datang, maka seharusnya investor dapat melakukan diversifikasi pada portofolio untuk meminimalkan risiko pada investasinya.

Tidak sedikit investor baru yang terjun ke pasar modal mengalami kerugian setelah harga saham yang mereka beli nilainya turun. Para pendatang baru ini banyak yang membeli saham tanpa memikirkan analisa teknikal dan fundamental, serta cenderung beli saham lantaran ikut-ikutan (www.Forum kontan.co.id, 2021). Survei Nasional Literasi Keuangan Indonesia (SNLKI) revisit 2017 yang dilakukan oleh Otoritas Jasa Keuangan (2017), Indeks Literasi Keuangan (ILK) masyarakat Indonesia pada tahun 2016 sebesar $29,7 \%$ yang mengartikan dari setiap 100 penduduk hanya 30 orang yang termasuk kategori well literate. Maka dapat diartikan bahwa masyarakat Indonesia belum sepenuhnya memiliki pengetahuan yang cukup untuk mengoptimalkan pengelolaan keuangan mereka.

Perilaku keuangan sangat dibutuhkan agar tidak salah mengelola keuangan khususnya dalam bidang investasi untuk meningkatkan ekonomi di masa depan. Shefrin (2000) mendefinisikan perilaku keuangan adalah studi yang mempelajari bagaimana fenomena psikologi mempengaruhi tingkah laku keuangannya yaitu mempelajari bagaimana manusia secara aktual berperilaku dalam sebuah penentuan keuangan. Rendahnya literasi masyarakat terhadap pasar modal berdampak dari rendahnya tingkat literasi masyarakat terhadap sektor keuangan, yang mana pasar modal merupakan sub sektor dari lembaga keuangan lain (Ramdani, et al., 2021).

Literasi keuangan dapat mempengaruhi pengambilan keputusan investasi karena investor yang memiliki pengetahuan keuangan yang baik dapat memprediksi investasi yang akan diambil, sehingga investasi yang diambil dapat menghasilkan keuntungan. Namun bukan hanya pengetahuan saja yang dibutuhkan, melainkan harus ditambah dengan keahlian dalam investasi. Pengetahuan keuangan yang dimiliki tiap individu berbeda-beda, hal ini memungkinkan pemilihan investasi yang berbeda-beda pula. Literasi keuangan yang tinggi dapat membantu investor dalam menentukan jenis investasi mana yang sesuai dengan dirinya.

Self control (kontrol diri) merupakan kekuatan kontrol atas diri oleh dirinya sendiri. Ini terjadi saat seseorang mencoba untuk mengubah cara bagaimana seharusnya individu berpikir, merasa atau berperilaku. Self control juga dapat diartikan kemampuan untuk berhati-hati dalam menggunakan uang yang dimiliki, dimana tidak melakukan pembelian tiba-tiba atau dengan kata lain menunda pembelian dengan pertimbangan dahulu supaya uangnya dapat digunakan sesuai rencana sehingga terhindar dari perilaku konsumtif.

Seorang investor selalu dihadapkan dengan keuntungan dan risiko. Semakin tinggi keuntungan yang diinginkan, akan semakin tinggi pula risiko yang akan dihadapi. Risiko adalah suatu ketidakpastian yang menimbulkan kerugian (loss) yang tidak diinginkan, apabila toleransinya terhadap risiko diabaikan, maka perencanaan dan pelaksanaannya dapat mengakibatkan risiko tidak sesuai dengan profil risikonya.

Risk tolerance adalah tingkat risiko yang masih dapat ditoleransi oleh seseorang. Setiap investor memiliki tingkat toleransi yang berbeda-beda terhadap investasi. Perbedaan toleransi setiap orang terhadap risiko disebabkan oleh banyak faktor, seperti pendapatan, status ekonomi, status karir, dan usia.

Adanya perbedaan tersebut, maka tingkat toleransi investor terhadap risiko mempunyai pengaruh terhadap pengambilan keputusan investasi. Jenis investasi dan banyaknya dana yang akan diinvestasikan dipengaruhi oleh toleransi seorang investor terhadap risiko yang biasa disebut dengan risk tolerance. Seorang investor selalu dihadapkan dengan 
keuntungan dan risiko. Indonesia masyarakatnya cenderung lebih mengenal produk perbankan seperti tabungan dan asuransi dari pada investasi. Masyarakat Indonesia masih lebih memilih aman dengan menempatkan uangnya yang memiliki risiko lebih kecil. Namun saat ini banyak masyarakat yang mulai menempatkan sebagian tabungannya untuk investasi.

Dalam penelitian ini, mengkaji keputusan investasi yang dilakukan oleh karyawan Bank. Dengan riset yang saya lakukan didapat informasi bahwa pengetahuan karyawan mengenai investasi di pasar modal belum cukup baik, di mana produk bank dan lembaga jasa keuangan lainnya berbeda. Karyawan bank sebagian besar memahami pengetahuan produk bank dan disarankan menggunakan produk bank tersebut yang akhirnya terbiasa dengan risiko yang aman.

Menurut Wood \& Zaichkowsky J.L. (2004) dalam penelitiannya mengungkap bahwa investor pria lebih toleran terhadap risiko dibandingkan dengan investor wanita. Investor wanita tergolong konservatif untuk investasi jangka panjang. Lutfi (2010) juga mengemukakan bahwa toleransi investor terhadap risiko lebih meningkat seiring dengan bertambahnya usia, namun investor menjadi seorang riskaverter ketika ia mendekati masa pensiun. Evan (2004) juga menyatakan bahwa investor yang lebih muda usianya (di bawah 30) cenderung menjadi risk seeker dibandingkan dengan investor yang berusia lebih tua (di atas 30). Berdasarkan latar belakang penelitian ini, maka peneliti tertarik untuk mengangkat judul Pengaruh Literasi Keuangan, Self Control dan Risk Tolerance terhadap Keputusan Investasi melalui Perilaku Keuangan (Studi Kasus Pada Karyawan BUMN di Kota Depok).

\section{TINJAUAN PUSTAKA}

\section{Literasi Keuangan}

Literasi keuangan adalah kebutuhan yang penting untuk terhindar dari madalah keuangan yang terjadi. Literasi keuangan dalam beberapa tahun terakhir memperoleh perhatian serius oleh semua kalangan. Menurut Atkinson dan Messy (2010), menyatakan bahwa literasi keuangan ialah kombinasi dari kesadaran, pengetahuan, keterampilan, sikap, dan perilaku yang diperlukan untuk membuat keputusan keuangan yang sehat yang tujuannya untuk memperoleh kesejahteraan keuangan.

\section{Self Control}

Self Control merupakan kemampuan individu dalam mengatur perilakunya, disaat individu menginginkan sesuatu dan dapat merubah emosinya untuk menahan dorongan tersebut. Banyak ahli yang mendefenisikan tentang kontrol diri, salah satunya adalah Nofsinger (2005) yang mengemukakan bahwasanya kontrol diri adalah kemampuan seseorang untuk dapat mengontrol diri dengan melawan keinginan untuk membelanjakan uang secara berlebihan, artinya mampu membelanjakan sesuai kebutuhan bukan keinginan.

\section{Risk Tolerance}

Menurut Halim (2005), toleransi risiko adalah tingkat kemampuan yang dapat diterima dalam mengambil suatu risiko investasi. Setiap investor mempunyai perbedaan dalam tingkat toleransi. Bila dikaitkan dengan preferensi investor terhadap risiko maka investor dibedakan menjadi tiga, pertama investor yang suka terhadap risiko, investor yang netral terhadap risiko, dan investor yang tidak menyukai risiko atau dengan kata lain menghindari risiko.

\section{Keputusan Investasi}

Menurut Tandelilin (2010), investasi adalah komitmen atas sejumlah dana atau sumber daya lainnya yang dilakukan pada saat ini dengan tujuan memperoleh sejumlah keuntungan di masa mendatang. Menurut Amri, kk (2021), keputusan investasi ialah keputusan ketika seseorang memutuskan untuk memilih investasi terbaik yang akan digunakan dalam memperoleh keuntungan dimasa depan. 


\section{Perilaku Keuangan}

Menurut Isfenti Sadalia dan Novi Andrani (2016: 1) perilaku keuangan merupakan bidang ilmu yang relatif baru yang bertujuan untuk menggabungkan teori psikologi perilaku dan kognitif dengan ekonomi konvensional dan keuangan untuk memberikan penjelasan mengapa orang mengambil keputusan keuangan yang tidak rasional. Perilaku keuangan berhubungan dengan tanggung jawab keuangan seseorang terkait dengan cara pengelolaan keuangannya. Tanggung jawab keuangan adalah bagaimana proses pengelolaan uang dan aset yang dilakukan secara produktif.

\section{METODE}

Jenis penelitian ini adalah kuantitatif dan bersifat ekspositori. Menurut Sugiyono (2018:8) penelitian kuantitatif adalah: "Metode penelitian yang berlandaskan pada filsafat positivisme, digunakan untuk meneliti pada populasi atau sampel tertentu, pengumpulan data menggunakan instrument penelitian, analisis data bersifat kuantutatif atau statistik, dengan tujuan untuk menguji hipotesis yang telah ditetapkan. Variabel penelitian ini ada variabel bebas $(X)$ yaitu literasi keuangan (X1), Self control (X2), dan Risk tolerance (X3). Variabel terikat (Y) yaitu keputusan investasi dan variabel intervening ( $Z$ ) adalah perilaku keuangan. Populasi penelitian ini adalah karyawan perbankan BUMN di Kota Depok, Jawa Barat, sehingga didapatkan sampel sebanyak 203 orang responden menggunakan rumus slovin. Instrument penelitian yang digunakan adalah angkat atau kuesioner yang disebarkan kepada sampel yang sudah ditentukan lalu alat ukurnya menggunakan skala likert. Teknik analisis data yang digunakan adalah Struktural Equation Modeling (SEM) menggunakan software SmartPLS.

\section{HASIL DAN PEMBAHASAN}

\section{Analisis Deskriptif}

Pada pengujian ini digunakan untuk mengetahui skor minimum dan maksimum, mean score dan standar deviasi dari masing-masing variabel. Adapun hasilnya sebagai berikut:

Tabel 1. Hasil Analisis Descriptive Statistics

Descriptive Statistics

\begin{tabular}{lc|r|r|r|r} 
& N & Minimum & Maximum & Mean & Std. Deviation \\
\hline Literasi Keuangan (X1) & 203 & 10 & 50 & 38.9 & 9.6 \\
\hline Self Control (X2) & 203 & 8 & 40 & 32.4 & 6.3 \\
\hline Risk Tolerance (X3) & & 16 & 40 & 33.4 & 4.2 \\
\hline Keputusan Investasi (Y) & 203 & 18 & 30 & 26.1 & 2.8 \\
\hline Perilaku Keuangan (Z) & & 9 & 45 & 35.2 & 7.3 \\
\hline Valid N (listwise) & 203 & & & & \\
\hline
\end{tabular}

Berdasarkan tabel di atas, maka didapat dari variabel Literasi Keuangan, skor yang minimum diperoleh responden adalah 10 sedangkan maksimumnya adalah 50 dengan rata-rata 38,9 dan standar deviasi 9,6. Kemudian untuk variabel Self Control skor minimum yang diperoleh adalah 8 sedangkan maksimumnya adalah 40 dengan rata-rata 32,4 dan standar deviasi 6,3. Variabel Risk Tolerance skor minimum yang diperoleh adalah 16 sedangkan maksimumnya adalah 40 dengan rata-rata 33,4 dan standar deviasi 4,2. Lalu untuk variabel Keputusan Investasi skor minimum yang diperoleh adalah 18 sedangkan maksimumnya adalah 30 dengan rata-rata 26,1 dan standar deviasi 2,8. Selanjutnya variabel Perilaku Keuangan skor minimum yang diperoleh adalah 9 sedangkan maksimumnya adalah 45 dengan rata-rata 35,2 dan standar deviasi 7,3.

\section{Analisis SEM Menggunakan SmartPLS}

Penelitian ini menggunakan analisis SEM dan aplikasi SmartPLS versi 
.0. Partial Least Square (PLS) adalah salah satu metode alternative Structural Equation Modeling (SEM) yang dapat digunakan untuk mengatasi permasalahan tersebut (Haryono, 2017). Adapun hasil pengujian sebagai berikut:

\section{a. Convergent Validity}

Pengujian Convergent Validity

\section{b. Discriminant Validity}

Pengukuran dengan discriminant validity menggunakan nilai cross loading dan nilai average variance extracted (AVE). Hasil pada pengujian ini yang menggunakan dari masing-masing indikator konstruk menurut Chin dalam Ghozali dan Latan (2015), suatu indikator dikatakan mempunyai valid jika nilainya lebih besar > 0,5. Berdasarkan hasil perhitungan seluruh indikator dapat penelitian ini sudah memiliki outer loading $>0,5$.

AVE menunjukkan bahwa nilai AVE yang dihasilkan pada setiap variabel yang digunakan lebih besar 0,5, maka dapat dikatakan memenuhi syarat yang disajikan pada tabel.

Tabel 2. Hasil Uji Average Variance Extracted (AVE)

\begin{tabular}{|l|c|c|}
\hline \multicolumn{1}{|c|}{ Variabel } & Average Variance Extracted (AVE) & Keterangan \\
\hline Literasi Keuangan & 0.758 & Valid \\
\hline Self Control & 0.707 & Valid \\
\hline Risk Tolerance & 0.585 & Valid \\
\hline Keputusan Investasi & 0.573 & Valid \\
\hline Perilaku Keuangan & 0.607 & Valid \\
\hline
\end{tabular}

Sumber: Hasil Pengujian SmartPLS, 2021

Berdasarkan tabel diatas dapat dilihat dari nilai AVE literasi keuangan $0.758>0,5$ valid, self control $0,707>0,5$ valid, risk tolerance $0.585>$ 0,5 valid, keputusan investasi $0.573>$ 0,5 valid, dan perilaku keuangan 0.607 $>0,5$ valid. Pengukuran kedua discriminant validity yang melihat dari setiap item pertanyaan dalam variabel dibandingkan setiap pertanyaan pada variabel lain. Berdasarkan hasil statistic menunjukkan bahwa nilai setiap pertanyaan menghasilkan cross loading > dalam melakukan perbandingan antar variabel pada setiap pertanyaan yang difungsikan

Tabel 3. Hasil Analisis Composite Reliability

\begin{tabular}{|c|c|c|}
\hline Variabel & Composite Reliability & Keterangan \\
\hline Literasi Keuangan & 0.969 & Reliable \\
\hline Self Control & 0.951 & Reliable \\
\hline Risk Tolerance & 0.908 & Reliable \\
\hline Keputusan Investasi & 0.889 & Reliable \\
\hline Perilaku Keuangan & 0.932 & Reliable \\
\hline
\end{tabular}

Sumber: Hasil Pengujian SmartPLS, 2021

Berdasarkan tabel diatas dapat dilihat bahwa seluruh variael dalam model penelitian ini reliabel karena

$$
\text { composite reliability }>0,7
$$

\section{d. Pengujian Cornbach's Alpha}

untuk mewakilinya.

\section{c. Composite Reliability}

Menurut Ghozali dan Latan (2015) pengujian composite reliability bertujuan untuk menguji reliabilitas instrumen dalam suatu model penelitian. Apabila seluruh nilai variabel laten memiliki nilai composite reliability $>0,7$ dan cronbach's alpha $>$ 0,7 hal itu berarti bahwa jawaban responden memiliki reliabilitas yang baik atau kuesioner yang digunakan sebagai alat dalam penelitian ini telah andal atau konsisten. Hasil pengujian dapat dilihat sebagai berikut: 
Pengukuran dengan pengujian ini dapat dinilai dengan cronbach's alpha harus lebih besar dari 0,7. Dapat dilihat pada Tabel di bawah ini bahwa nilai cronbach's alpha masing-masing

Tabel 4. Hasil Pengu variabel memiliki nilai lebih besar dari 0,7 maka dapat dinyatakan jawaban responden pada setiap variabel konsisten.

\begin{tabular}{|c|c|c|}
\hline \multicolumn{2}{|c|}{ Tabel 4. Hasil Pengujian Pengujian Cronbach's Alpha } \\
\hline Variabel & Cronbach's Alpha & Keterangan \\
\hline Literasi Keuangan & 0.964 & Reliable \\
\hline Self Control & 0.940 & Reliable \\
\hline Risk Tolerance & 0.882 & Reliable \\
\hline Keputusan Investasi & 0.889 & Reliable \\
\hline Perilaku Keuangan & 0.917 & Reliable \\
\hline
\end{tabular}

\section{e. $\mathbf{R}$ Square $\left(\mathbf{R}^{2}\right)$}

Sumber: Hasil Pengujian SmartPLS, 2021

Menurut Ghozali dan Latan (2015), perubahan nilai R-squares dapat digunakan untuk menilai pengaruh variabel laten independen tertentu terhadap variabel laten dependen apakah mempunyai pengaruh yang substantive. Hasil R2 sebesar 0.67, 0.33 dan 0.19 untuk variabel laten endogen dalam model struktural mengindikasikan bahwa model "kuat", "moderate" dan "lemah" (Ghozali dan Latan, 2015).

Pengujian ini digunakan untuk menentukan model yang dibentuk layak atau tidak untuk diteliti.

Tabel 5. Hasil R ${ }^{2}$ Setiap Variabel

\begin{tabular}{|c|c|}
\hline Variabel & R Square \\
\hline Keputusan Investasi & 0.588 \\
\hline Perilaku Keuangan & 0.480 \\
\hline
\end{tabular}

Sumber: Hasil Pengujian SmartPLS, 2021

Berdasarkan tabel diatas dapat dilihat nilai $\mathrm{R}^{2}$ untuk Perilaku Keuangan sebesar 0.588 yang berarti bahwa termasuk ke dalam kategori moderate (sedang). Sehingga dapat disimpulkan bahwa Literasi
Keuangan, Self Control dan Risk Tolerance memberikan dampak yang Moderate terhadap Perilaku Keuangan. Nilai $\mathrm{R}^{2}$ untuk Keputusan Investasi sebesar 0.480 yang berarti bahwa termasuk ke dalam kategori moderate (sedang). Sehingga dapat disimpulkan bahwa Literasi Keuangan, Self Control dan Risk Tolerance dan Perilaku Keuangan. memberikan dampak yang sedang terhadap Keputusan Investasi.

\section{f. Effect Size $\left(\mathrm{F}^{2}\right)$}

Nilai effect Size $\left(\mathrm{f}^{2}\right)$ juga digunakan untuk mengevaluasi apakah ketika variabel eksogen dihilangkan memiliki dampak yang subtantif terhadap variabel endogen. Nilai $\mathrm{f}^{2}$ sebesar $0,02,0,15$, dan 0,35 dapat diinterpretasikan apakah predicator variabel laten memiliki pengaruh yang kecil, menengah, dan besar pada tingkat struktural menurut Chin (1998) dalam Ghozali dan Latan (2015). Pada Tabel diatas ditunjukan nilai effect Size $\left(\mathfrak{f}^{2}\right)$ dari setiap variabel eksogen terhadap variabel endogen.

Tabel 6. Nilai Effect Size (VIF)

\begin{tabular}{|c|c|c|}
\hline Variabel & Perilaku Keuangan & Keputusan Investasi \\
\hline Literasi Keuangan & 2.014 & 2.479 \\
\hline Self Control & 1.880 & 1.986 \\
\hline Risk Tolerance & 1.240 & 1.243 \\
\hline Perilaku Keuangan & & 1.922 \\
\hline
\end{tabular}

Sumber: SmartPLS, 2021

Berdasarkan hasil di atas dapat dilihat Literasi Keuangan, Self Control

dan Risk Tolerance masing-masing memiliki nilai 2.014, 1.880 dan 1.240 

pengaruh besar terhadap Perilaku Keuangan. Nilai effect Size $\left(\mathrm{f}^{2}\right)$ masingmasing Literasi Keuangan, Self Control dan Risk Tolerance dan Perilaku Keuangan terhadap Keputusan Investasi memiliki nilai 2.479, 1.986, 1.243 dan 1.922. Hal ini menunjukkan bahwa terdapat satu variabel yang mempunyai pengaruh menengah Risk Tolerance, sedangkan ketiga varaibel lainnya memiliki pengaruh besar terhadap Keputusan Investasi. yang ketiganya mempunyai terhadap Keputusan Investasi yaitu

g. Nilai Coefficient Jalur

Dari hasil coefficient jalur maka dapat dibuat persamaan model struktural sebagai berikut:

$Z=0.492 X_{1}+0.235 X_{2}+0.041 X_{3}$ $Y=0.190 X_{1}+0.250 X_{2}+0.123 X_{3}+$ $0.369 \mathrm{Z}$

\section{Pengujian Hipotesis}

Pengujian hipotesis penelitian menggunakan koefisien $t$-statistic. Dimana hasil/output dari perintah bootstrapping menghasilkan t-statistic. Indikator yang memiliki t-statistic > 1,96 dikatakan signifikan (Ghozali dan Latan, 2015). Indikator juga dapat dikatakan berpengaruh jika memiliki p-value < 0,05 (Haryono, 2017).

Tabel 7. Pengujian Pengaruh Langsung

\begin{tabular}{|l|c|c|c|c|c|}
\hline \multicolumn{1}{|c|}{ Variabel } & $\begin{array}{c}\text { Original } \\
\text { Sample (O) }\end{array}$ & $\begin{array}{c}\text { Sample } \\
\text { Mean (M) }\end{array}$ & $\begin{array}{c}\text { Standard } \\
\text { Deviation } \\
(\text { STDEV) }\end{array}$ & $\begin{array}{c}\text { T Statistics } \\
(\mid \mathrm{O} / \text { STDEV } \mid)\end{array}$ & $\begin{array}{c}\mathrm{P} \\
\text { Values }\end{array}$ \\
\hline $\begin{array}{l}\text { Literasi Keuangan } \rightarrow \\
\text { Perilaku Keuangan }\end{array}$ & 0,492 & 0,485 & 0,094 & 5,251 & 0,000 \\
\hline $\begin{array}{l}\text { Self Control } \rightarrow \\
\text { Perilaku Keuangan }\end{array}$ & 0,235 & 0,236 & 0,101 & 2,326 & 0,020 \\
\hline $\begin{array}{l}\text { Risk Tolerance } \rightarrow \\
\text { Perilaku Keuangan }\end{array}$ & 0,041 & 0,044 & 0,057 & 0,712 & 0,476 \\
\hline $\begin{array}{l}\text { Literasi Keuangan } \rightarrow \\
\text { Keputusan Investasi }\end{array}$ & 0,190 & 0,197 & 0,072 & 2,657 & 0,008 \\
\hline $\begin{array}{l}\text { Self Control } \rightarrow \\
\text { Keputusan Investasi }\end{array}$ & 0,250 & 0,256 & 0,071 & 3,539 & 0,000 \\
\hline $\begin{array}{l}\text { Risk Tolerance } \rightarrow \\
\text { Keputusan Investasi }\end{array}$ & 0,123 & 0,122 & 0,049 & 2,496 & 0,013 \\
\hline $\begin{array}{l}\text { Perilaku Keuangan } \rightarrow \\
\text { Keputusan Investasi }\end{array}$ & 0,369 & 0,358 & 0,075 & 4,932 & 0,000 \\
\hline
\end{tabular}

Sumber: Hasil Pengujian SmartPLS, 2021

Berdasarkan tabel diatas dapat disimpulkan hasil pengujian hipotesis model penelitian:

- Literasi Keuangan mempunyai nilai $\mathrm{t}$ statistic $5.251>1,96$, $\mathrm{p}$ value $0.000<0,05$ dan original sample 0.492 maka $\mathrm{H}_{1}$ diterima, artinya Literasi Keuangan berpengaruh positif dan signifikan terhadap Perilaku Keuangan.

- Self Control mempunyai nilai $\mathrm{t}$ statistic $2.326>1,96$, p value 0,020 $<0,05$ dan original sample 0.235 maka $\mathrm{H}_{2}$ diterima, artinya Self Control berpengaruh positif dan signifikan terhadap Perilaku Keuangan.

- Risk Tolerance mempunyai nilai $\mathrm{t}$ statistic $0.712>1,96$, p value 0.476 $>0,05$ dan original sample 0.041 maka $\mathrm{H}_{3}$ ditolak, artinya Risk Tolerance tidak berpengaruh positif dan signifikan terhadap Perilaku Keuangan.

- Literasi Keuangan mempunyai nilai $t$ statistic $2.657>1,96$, $p$ value $0.008<0,05$ dan original sample 0.190 maka $\mathrm{H}_{4}$ diterima artinya Literasi Keuangan berpengaruh 
positif dan signifikan terhadap Keputusan Investasi.

- Self Control mempunyai nilai $\mathrm{t}$ statistic $3.539>1,96, \mathrm{p}$ value 0.000 $<0,05$ dan original sample 0.250 maka $\mathrm{H}_{5}$ diterima, artinya Self Control berpengaruh positif dan signifikan terhadap Keputusan Investasi.

- Risk Tolerance mempunyai nilai $\mathrm{t}$ statistic $2.496>1,96$, p value 0.013 $<0,05$ dan original sample 0.123 maka $\mathrm{H}_{6}$ diterima, artinya Risk Tolerance berpengaruh positif dan signifikan terhadap Keputusan Investasi.

- Perilaku Keuangan mempunyai nilai $\mathrm{t}$ statistic $4.932>1,96$, $\mathrm{p}$ value $0.000<0,05$ dan original sample 0.369 maka $\mathrm{H}_{7}$ diterima, artinya Perilaku Keuangan berpengaruh positif dan signifikan terhadap Keputusan Investasi.

Sementara kalian dilihat berdasarkan pengujian antar variabel dapat dinyatakan bahwa:

$\begin{array}{llr}\text { a. Variabel } & \text { Literasi } & \text { Keuangan } \\ \text { signifikan } & \text { terhadap } & \text { variabel }\end{array}$ Keputusan Investasi melalui Perilaku keuangan dengan nilai $\mathrm{p}$ value sebesar $0.000<0.05$.

b. Variabel Self Control signifikan terhadap variabel Keputusan Investasi melalui Perilaku keuangan dengan nilai $\mathrm{p}$ value sebesar $0.026<0.05$.

c. Variabel Risk Tolerance tidak signifikan terhadap variabel Keputusan Investasi melalui Perilaku keuangan dengan nilai $\mathrm{p}$ value sebesar $0.502>0.05$.

d. Berdasarkan hasil rangkuman pengaruh langsung, maka dapat diketahui bahwa nilai koefisien jalur Literasi Keuangan terhadap Perilaku Keuangan mempunyai nilai t-statistic 5.251, yang berarti bahwa Literasi Keuangan memiliki hubungan positif dan siginfikan terhadap Keputusan Investasi. Nilai koefisien jalur Self Control terhadap Perilaku Keuangan sebesar 2.326, yang berarti bahwa Self Control memiliki hubungan positif terhadap Perilaku Keuangan dan nilai koefisien jalur Risk Tolerance terhadap Perilaku Keuangan sebesar 0,712 yang berarti bahwa Risk Tolerance tidak memiliki hubungan positif terhadap Perilaku Keuangan. Nilai koefisien jalur Literasi Keuangan terhadap Keputusan Investasi sebesar 2.657, yang berarti bahwa Literasi Keuangan memiliki hubungan positif terhadap Keputusan Investasi. Nilai koefisien jalur Self Control terhadap Keputusan Investasi sebesar 3.539, yang berarti bahwa Self Control memiliki hubungan positif terhadap Keputusan Investasi. Nilai koefisien jalur Risk Tolerance terhadap Keputusan Investasi sebesar 2.496, yang berarti bahwa Risk Tolerance memiliki hubungan positif terhadap Keputusan Investasi dan nilai koefisien jalur Perilaku Keuangan terhadap Keputusan Investasi sebesar 4.932, yang berarti bahwa Perilaku Keuangan memiliki hubungan positif terhadap Keputusan Investasi.

\section{PEMBAHASAN HASIL PENELITIAN}

1. Pengaruh Literasi Keuangan terhadap Perilaku Keuangan

Hasil dari penelitian yang telah diperoleh bahwa Literasi Keuangan berpengaruh positif signifikan terhadap Perilaku Keuangan, artinya semakin tinggi tingkat literasi keuangan yang dimilikinya, maka semakin baik perilaku keuangan individu dalam mengelola pendapatan dan assetnya sehingga diharapkan daapt memberikan manfaat dalam keuangannya baik dalam jangka pendek maupun jangka panjang. Literasi keuangan membantu individu dalam memberikan pemahaman mengenai pengelolan keuangan dan kesempatan 
untuk hidup lebih sejahtera di masa depan. Theory of Reasoned Action (TRA) mengartikan perilaku individu ditentukan oleh suatu intensi yang menjadi fungsi dari tingkah laku terhadap perilaku norma subjektif. Intensi ini dapat memprediksi perilaku seseorang dengan sangat baik dan ditentukan oleh tiga hal, yaitu: pengendalian perilaku, norma dan norma subjektif.

\section{Pengaruh Self Control terhadap} Perilaku Keuangan

Hasil dari penelitian yang telah diperoleh bahwa Self Control berpengaruh positif signifikan terhadap Perilaku Keuangan, artinya semakin baik self control (kontrol diri) yang dimiliki maka akan berdampak pada perilaku keuangan yang baik pula, individu akan lebih memiliki tanggungjawab dalam perilakunya untuk mengelola asset yang dimiliki. Dengan self control ini seseorang akan mampu mengatur dan membimbing perilakunya. Self control ini dapat mempengaruhi seseorang dalam mengolah keuangan yang dapat menjadikannya lebih memperhatikan tindakan yang dilakukan dan efeknya setelah terjadi. Penelitian terdahulu yang dilakukan oleh Perry dan Moris (2005) tentang financial behaviour, mengatakan bahwa: pertama, kontrol diri (self control) seseorang terhadap apapun yang terjadi dalam kehidupan; kedua, pengetahuan keuangan seseorang terhadap hal yang berhubungan dengan uang; ketiga, tingkat pendapatan seseorang.

3. Pengaruh Risk Tolerance terhadap Perilaku Keuangan

Hasil dari penelitian yang telah diperoleh bahwa Risk Tolerance tidak berpengaruh positif terhadap Perilaku Keuangan, artinya rendahnya toleransi investor terhadap risiko dari investasi menyebabkan investor dalam perilaku keuangannya tidak berhati-hati dalam memilih investasi yang berisiko tinggi. Pengetahuan responden mengenai investasi di pasar modal belum cukup baik, di mana produk bank dan lembaga jasa keuangan lainnya berbeda. Responden sebagian besar memahami pengetahuan produk bank dan disarankan menggunakan produk bank tersebut yang akhirnya terbiasa dengan risiko yang aman. Sedangkan pengetahuan mengenai pasar modal meliputi pengetahuan substansial, analisa emiten dan peraturan-peraturan terkait dengan pasar modal lainnya.

4. Pengaruh Literasi Keuangan terhadap Keputusan Investasi

Hasil dari penelitian yang telah diperoleh bahwa Literasi Keuangan berpengaruh positif signifikan terhadap Keputusan Investasi, artinya semakin baik literasi keuangan yang dimiliki, maka semakin baik pula kualitas keputusan investasi yang diambil. Sehingga dapat mencapai perencanaan keuangan yang baik untuk kesejahteraan dalam hidup dan keinginan untuk berinvestasi semakin tinggi. Menurut Williamson (1998) mengemukakan bahwa individu dengan pengetahuan yang kurang cenderung memiliki pendapat yang salah dan membuat keputusan yang salah dalam bidang investasi, tabungan, pengetahuan umum dan pinjaman. Maka, dengan meningkatkan pengetahuan dan kemampuan keuangan pribadi menjadi hal penting, tanpa pengetahuan yang memadai, mereka lebih cenderung membuat keputusan yang salah.

5. Pengaruh Self Control terhadap Keputusan Investasi

Hasil dari penelitian yang telah diperoleh bahwa Literasi Keuangan berpengaruh positif signifikan terhadap Keputusan Investasi, artinya semakin baik pengendalian diri yang dimiliki individu, maka semakin baik pula invdividu dapat mengendalikan emosi dalam mengontrol keputusannya dengan melakukan pertimbangan dengan bijak, sehingga keputusan yang diambil tidak salah. Investor yang memiliki self control mampu untuk berhati-hati dalam menggunakan uang yang dimiliki, dengan tidak melakukan 
pembelian/investasi saham secara spontan tanpa pertimbangan dan melakukan analisis risiko dari investasi yang dilakukan.

6. Pengaruh Risk Tolerance terhadap Keputusan Investasi

Hasil dari penelitian yang telah diperoleh bahwa Risk Tolerance berpengaruh positif signifikan terhadap keputusaan investasi, artinya semakin tinggi tingkat toleransi investor, maka akan semakin tinggi pula preferensi keputusan investasi dalam saham yang berrsedia diambil oleh investor. Semakin besar keuntungan yang diharapkan, maka akan semakin besar pula tingkat risiko yang harus ditanggung investor. Setiap investor memiliki tingkat petbedaan dalam risk tolerance. Sehingga diharapkan investor memahami terlebih dahulu tingkat kemampuan risiko yang dapat mereka terima dalam mengambil suatu risiko investasi. Investor yang rasional tentu mempertimbangkan dahulu dalam memilih investasi dan mempertimbangkan besarnya uang yang akan diinvestasikan. Bailey dan Kinerson (2005) menemukan bahwa risk tolerance merupakan salah satu faktor yang sangat kuat dalam pengambilan keputusan investasi.

7. Pengaruh Perilaku Keuangan terhadap Keputusan Investasi

Hasil dari penelitian yang telah diperoleh bahwa perilaku keuangan berpengaruh positif signifikan terhadap keputusaan investasi, artinya semakin baik perilaku keuangan yang dimiliki individu dalam mengelola keuangannya, maka semakin baik pula individu dalam membuat keputusan investasi demi mengembangkan dananya di tempat yang sesuai. Perilaku keuangan merupakan bentuk penggabungan dari segi kemampuan keuangan dan kemampuan psikologis seseorang dalam memanfaatkan dan mengelola sumber daya keuangannya sebagai dasar pengambilan keputusan untuk perencanaan keuangan dan investasi. Dalam ilmu behavioral finance fenomena/faktor

psikologi mempengaruhi perilaku keuangan dan bagaimana emosi/perasaan mempengaruhi pembuatan keputusan seseorang. Jogiyanto (2010) menyatakan bahwa dalam Teori Ekspektasi Rasional investor yang tidak mempunyai ilmu dan informasi akan melakukan

transaksi (pembelian/penjualan) saham dengan mengikuti transaksi yang dilakukan oleh investor yang memiliki ilmu dan informasi. Sehingga mereka hanya meniru keputusan investor lain dengan mengharap return yang tinggi.

\section{PENUTUP}

\section{Kesimpulan}

a. Keuangan berpengaruh terhadap Perilaku Keuangan. Hal ini berpengaruh karena literasi keuangan yang dimiliki pada responden terus ditingkatkan. Investor dalam pengambilan keputusan selalu berusaha untuk mengambil keputusan secara rasional, tetapi seiring dengan waktu faktor psikologi juga mempengaruhi dalam menentukan investasi. Dengan adanya faktor-faktor psikologi sosial, yaitu kecenderungan perilaku investor mengikuti cara investasi suatu kelompok atau investor lain dan mengikuti investor asing yang dianggap investor domestik lebih piawai. Namun investor (karyawan Bank) berusaha meningkatkan pengetahuan untuk memaksimalkan informasi, pengetahuan, pemahaman serta penggunaan instrumeninstrumen dan produk-produk keuangan di pasar modal sehingga perilaku keuangan investor dapat dikendalikan sesuai pengalaman dan rencana investasi

b. Self Control berpengaruh terhadap Perilaku Keuangan. Hal ini berpengaruh karena self control yang dimiliki oleh responden dianggap sebagai pendorong dari dalam diri seseorang untuk mengontrol 
tindakan dalam mengatur perilaku keuangan pribadinya dengan mengendalikan diri akan emosinya untuk mengurangi pengeluaran yang tidak diperlukan, teliti dalam menempatkan dana investasi dan selalu berusaha mengevaluasi setiap aktivitas investasinya. Self control sangat berpengaruh dalam mencapai kesuksesan keuangan. Jika tidak adanya self control yang baik dalam diri investor, maka akan sulit investor mengatur dirinya dalam mengalokasikan dana yang dimiliki sesuai rencana. Dalam theory of planned behaviour menerangkan perilaku individu tidak saja dipengaruhi oleh dirinya tetapi juga kontrol yang lain dan konsep kontrol perilaku yang mempengaruhi niat dan perilaku.

c. Risk Tolerance tidak berpengaruh terhadap Perilaku Keuangan. Hal ini disebabkan karena responden dalam penelitian ini memiliki tingkat toleransi yang berbeda-beda dan tidak terlalu tinggi sehingga perilaku keuangan responden cenderung di posisi yang aman. Tingkat risiko yang dimiliki setiap responden tidak berpengaruh banyak terhadap perilaku dan pemilihan investasi yang ada. Setiap responden memiliki gagasan dan pengetahuan terhadap investasi sehingga risk tolerance-nya tidak tinggi. Kurangnya pemahaman responden terhadap instrumen investasi ini mempengaruhi psikologi responden terhadap risk tolerance. Pengetahuan responden mengenai investasi di pasar modal belum cukup baik, di mana produk bank dan lembaga jasa keuangan lainnya berbeda. Responden sebagian besar memahami pengetahuan produk bank dan disarankan menggunakan produk bank tersebut yang akhirnya terbiasa dengan risiko yang aman. Sedangkan pengetahuan mengenai pasar modal meliputi pengetahuan substansial, analisa emiten dan peraturan-peraturan terkait dengan pasar modal lainnya.

d. Literasi Keuangan berpengaruh terhadap Keputusan Investasi. Hal ini berpengaruh karena dengan literasi keuangan ini dapat meningkatkan informasi, pengetahuan dan pemahaman serta penggunaan instrumen-instrumen dan produkproduk keuangan yang ada. Dengan meningkatnya literasi keuangan yang didapatkan investor, maka semakin tinggi pula minat individu untuk menginvestasikan uangnya di investasi saham.

e. Self Control berpengaruh terhadap Keputusan Investasi. Hal ini berpengaruh karena dengan Self Control ini individu dapat mengontrol tindakannya dalam merencanakan keuangan pribadinya, lebih berhatihati dalam mengambil keputusan, tidak tergiur dengan rekomendasi orang lain yang belum jelas dan terus meningkatkan pengetahuan tentang seluk beluk investasi saham ini.

f. Risk Tolerance berpengaruh terhadap Keputusan Investasi. Hal ini berpengaruh karena responden mulai belajar beralih dari investasi yang memiliki risiko rendah ke investasi yang memiliki risiko tinggi. Dengan meningkatkan keberanian terhadap risiko untuk mendapat return yang lebih tinggi kemudian dapat mempengaruhi keputusan yang diambil oleh responden dalam menempatkan dana investasi.

g. Perilaku Keuangan berpengaruh terhadap Keputusan Investasi. Hal ini berpengaruh karena responden mulai berminat untuk investasi pada instrumen yang lebih menguntungkan dengan mengontrol sikap, mental dan keterampilan dalam mengelola uangnya. Dapat mengatur keinginan dan emosinya dalam menggunakan uang secara bijak serta dapat menyisihkan dana untuk diinvestasikan. Sehingga dapat mempengaruhi responden dalam 
menentukan keputusan keuangan dan investasi.

\section{Saran}

a. Bagi peneliti selanjutnya, disarankan untuk melakukan penelitian lebih spesifik dan mengembangkan serta memperbanyak indikator dari variabel-variabel yang telah diteliti ini dan variabel lain, agar hasil yang didapat bisa lebih baik karena dunia investasi terus berkembang berikut juga dengan produk investasi yang ada di pasar modal.

b. Bagi investor, diharapkan terus meningkatkan pengetahuan, informasi dan keterampilan dalam investasi melalui berbagai media yang ada, serta harus aktif mengamati kondisi dan situasi peluang pasar agar memahami betul tentang dunia investasi. Sehingga risiko yang akan dihadapi dalam investasi dapat diminimalkan, yang pada akhirnya akan membuat hidup lebih sejahtera di masa depan dan tidak mudah terpengaruh oleh ajakan orang lain atau iming-iming dengan keuntungan yang besar.

c. Bagi akademisi, disarankan dapat terus memberi pengetahuan tentang literasi keuangan kepada mahasiswa, diharapkan dengan pengetahuan ini dapat membuat perilaku keuangan dalam kehidupannya terencana dengan baik.

\section{DAFTAR PUSTAKA}

Amri, A. (2021). Mediasi Kepuasan Kerja: Komunikasi , Komitmen Dan Disiplin Kerja Serta Dampaknya Pada Kinerja Karyawan ( Studi Kasus Pada Radio Republik Indonesia ( RRI ) Padang ) Radio Radio Republik Indonesia ( RRI ) Padang y. Strategic: Journal of Management Sciences, 1(3), 94-112.

Aminatuzzahra. (2014). Persepsi Pengaruh Pengetahuan Keuangan, Sikap Keuangan, Sosial Demografi Terhadap Perilaku Keuangan Dalam
Pengambilan Keputusan Investasi Individu. Bisnis Strategi, 23 (2), 70-96.

Amri, A., \& Ramdani, Z. (2020). Pengaruh nilai tukar, kebijakan deviden dan struktur modal terhadap return saham pada perusahaan yang terdaftar di jakarta islamic index. Jurnal Ilmu Keuangan Dan Perbankan (JIKA), 10(1), 17-36. https://doi.org/10.34010/JIKA.V10I1.355 6

Amri, A., Ramdani, Z., Warsihna, J., \& Tae, L. F. (2021). Tungku tigo sajarangan, tali tigo sapilin: A strategy towards world class university based on local wisdom perspective. Al-Ishlah: Jurnal Pendidikan, 13(1), 31-40. https://doi.org/10.35445/alishlah.v13i1.3 86

Amri, A., Widyastuti, T., \& Bahri, S. (2021). Analisis korelasional financial attitude, financial knowledge dan spiritual intelligence pada mahasiswa pascasarjana. Jurnal Ekonomi Syariah, 6(1), 16-27. https://doi.org/10.37058/jes.v6i1.

Bailey, J. J., \& Kinerson, C. (2005). Regret Avoidance and Risk Tolerance. Journal of Financial Counseling and Planning,16 (1), 23.Bongomin, G. O. C., Ntayi, J. M., Munene, J. C. dan Nabeta, I. N. 2016.

"Behavioral Finance: Kognisi \& Emosi Dalam Berinvestasi". https:/ / reksadanamanulife.com/file/edisi-27-oktober2015.pdf[5 April 2019]OECD. 2006.

Berita Pers, melalui Sinergi Perbankan dan Pasar Modal, Investor di Bandung Bisa Tarik Dana Lewat Atm. http://www.ksei.co.id/files/upload s/

press_releases/press_file/id/106_sia ran_pers_melalui_sinergi_perbankan _dan_pasar_modal_investor_di_band ung_bisa_tarik_dana_lewat_atm_201 51208153715.pdf [23 April 2019] Manulife Asset Managment. 2015.

Budiarto, A. (2017). Pengaruh Financial Literacy, Overconfidence, Regret Aversion Bias, Dan Risk Tolerance Terhadap Keputusan Investasi (Studi pada Investor PT. Sucorinvest Central 
Gani Galeri Investasi BEI Universitas Negeri Surabaya). Jurnal Ilmu Manajemen (JIM), 5(2), 1-9.

Chotimah, C., \& Rohayati, S. (2015). Pengaruh Pendidikan Keuangan Di Keluarga, Sosial Ekonomi Orang Tua, Pengetahuan Keuangan, Kecerdasan Spiritual, Dan Teman Sebaya Terhadap Manajemen Keuangan Pribadi Mahasiswa S1 Pendidikan Akuntansi Fakultas Ekonomi Universitas Negeri Surabaya. Jurnal Pendidikan Akuntansi (JPAK), 3(2), 1-10.

Ghozie, Prita Hapsari, (2018), Make It Happen!, Jakarta: PT Gramedia.

Grable, J. E. \& Lytton, R. H. 1998. Investor Risk Tolerance: Testing the Efficacy of Demographics as Differentiating and Classifiying Factors. Financial Counceling and Planning.

Grable, J. E. (2000). Financial Risk Tolerance and Additional Factors That Affect Risk Taking In Everyday Money Matters. Journal of Business and Psychology, 14(4), 239-248.

Herawati, N. T., Candiasa, I. M., Yadnyana, I. K., \& Suharsono, N. (2018). Factors That Influence Financial Behavior Among Accounting Students in Bali. International Journal of Business Administration, $\quad 9(3), \quad 30$. https://doi.org/10.5430/ijba.v9n3p3 $\underline{0 .}$

Herawati, N. T., \& Dewi, N. W. Y. (2020). The Effect of Financial Literacy, Gender, and Students' Income on Investment Intention: The Case of Accounting Students. 394(Icirad 2019), 133-138. https://doi.org/ 10.2991/assehr.k.200115.022

Hilgert, M., Hogarth, J., \& Beverly, S. (2003). Household financial management: the connection between knowledge and behavior. Federal Reserve Bulletin, Jul, 309-322.

Jogiyanto, Hartono. (2010). Teori Portofolio dan Analisis Investasi. Edisi Ketujuh. Yogyakarta: BPFE-Yogyakarta.

Jurnal Ilmu Manajemen (JIM), 5 (2). Byrne, A. 2007. Employee saving and investment decisions in defined contribution pension plans: survey evidence from the UK. Financial Services Review,16 (1). Kartini, K., \& Nugraha, N. F. 2015.

Jurnal Ilmu Manajemen Volume 6 Nomor 3 -Jurusan Manajemen Fakultas Ekonomi Universitas Negeri SurabayaPradikasari, Ellen. 2018.

Jurnal Ilmu Manajemen Volume 05 Nomor 02 -Jurusan Manajemen Fakultas Ekonomi Universitas Negeri SurabayaGhozali, I. 2018.

Ni Putu \& Astrie K, 2020, Pengaruh Financial Literacy, Risk Tolerance dan Overconfidence terhadap Pengambilan Keputusan Investasi pada usia produktif di Kota Bandung.

Pompian, Michael M., Behavioral Finance and Wealth Management (New York: Jhon Wiley \& Sons, 2012).

Pradhana, Rafinza Widiar, 2018, Pengaruh Financial Literacy, Cognitive Bias, dan Emotional Bias terhadap Keputusan Investasi (Studi Pada Investor Galeri Investasi Universitas Negeri Surabaya).

Pradikasari, E., \& Isbanah, Y. (2018). Pengaruh Financial Literacy, Illusion of Control, Overconfidence, Risk Tolerance, dan Risk Perception Terhadap Keputusan Investasi Pada Mahasiswa di Kota Surabaya. Jurnal Ilmu Manajemen (JIM), 6(4), 424-434.

PISA 2015 Assessment and Analytical Framework: Science, Reading, Mathematic, Financial Literacy and Collaborative Problem Solving, revised edition. Paris: OECD.Otoritas Jasa Keuangan. 2017. Survei Nasional Literasi Keuangan Indonesia (revisit 2017). Jakarta: OJK.

Putri, Dwiyana Rasuma. 2017. Pengaruh Tingkat Literasi keuangandan Faktor Sosiodemografi Terhadap Perilaku Keputusan Investasi Individu. EJurnal Ekonomi dan Bisnis Universitas Udayana 6.9 (2017): 3407343

Ramadhi, Amri, A., \& Ramdani, Z. (2021). Studi 
terhadap faktor-faktor yang menentukan kinerja seorang karyawan. Jurnal Sains Manajemen, 7(2), 129-143.

Ramdani, Z., Amri, A., Warsihna, J., Ratna Garnasih, T., \& Juarsa, E. (2021). Perilaku manajemen keuangan karyawan selama pandemi COVID-19: sebuah studi awal. Jurnal Ekonomi Dan Bisnis Islam, 8(1), 170-179.

Rachbini, Dr. Widarto, Prof. Dr. Didik J. Rachbini, dkk. (2020), Metode Riset Ekonomi \& Bisnis (Analisis RegresiSPSS \& SEM-Lisrel), Jakarta: INDEF.

Sugiyono. 2017. Metode Penelitian Pendidikan Pendekatan Kuantitatif, kualitatif, dan R\&D.Bandung: Alfabeta.Sunariyah. 2011. Pengantar Pengetahuan Pasar Modal Edisi Enam. Yogyakarta: Sekolah Tinggi Ilmu Manajemen.

Ullah, S. 2015. An Empirical Study of Illusion of Control and Self-Serving Attribution Bias, Impact on Investor's

Sholeh, Badrus, 2019. Pengaruh Literasi Keuangan Terhadap Perilaku Keuangan Mahasiswa Program Studi
Pendidikan Ekonomi Universitas Pamulang.

Kemenkeu. 2018. Ini Indikator-Indikator Perekonomian Indonesia Positif. https://www.kemenkeu.go.id/publi kasi/berita/ini-indikator-indikatorperekonomian-indonesia-positif/[5 April 2019]KSEI. 2015.

Gailliot, M. T., Baumeister, R. F., Dewall, C. N., Maner, J. K., Plant, E. A., Tice, D. M. Brewer, L. E. \& Schmeichel, B. J (2007) Self Control relies on glucose as limited energy source: willpower is niore than a metaphor. Journal of personality and social Psychology, 92 (2): 325-336.

Wulandari, Dewi Ayu \& Rr. Iramani, (2014), Studi Experienced Regret, Risk Tolerance, Overconfidance Dan Risk Perception Pada Pengambilan Keputusan Investasi Dosen Ekonomi. Journal of Business and Banking 4 (1), 5566. 